\title{
EFFECT OF GERMINATION ON MAIN PHYSIOLOGY AND BIOCHEMISTRY METABOLISM OF SORGHUM SEEDS
}

\author{
EFEITO DA GERMINAÇÃO NO PRINCIPAL METABOLISMO FISIOLOGICO E \\ BIOQUÍMICO DE SEMENTES DE SORGO
}

\author{
Runqiang YANG ${ }^{1}$; Peng WANG ${ }^{1}$; Maha F. ELBALOULA ${ }^{1,2}$; Zhenxin GU ${ }^{1}$ \\ 1. College of Food Science and Technology, Nanjing Agricultural University, Nanjing 210095, People's Republic of China; 2. \\ Department of Food Science and Technology, College of Agricultural Studies, Sudan University of Science and Technology. Bahri- \\ Shambat, Khartoum, 13314, Sudan. guzx@ njau.edu.cn
}

\begin{abstract}
The main physiology and biochemistry metabolism including amino acids composition and gamma-aminobutyric acid (GABA) content of sorghum during 3-day germination period was investigated. Respiratory rate increased during germination. Protease activity, free amino acid and reducing sugar content increased with germination time. While moisture, protein, fat and starch content decreased, significantly. Meanwhile, amino acid composition redistributed and the relative content of essential amino acids increased except for leucine and valine. In addition, some nonessential amino acids content such as proline, glycine and histidine was largely enhanced by germination. GABA content increased about 3 folds after germination. Furthermore, combining tannin (the main antinutritional factor) was converted to be free and solvable. These results greatly suggest that germinated sorghum could be a functional food rich in GABA and other health-promoting nutrients.
\end{abstract}

KEYWORDS: Sorghum. Germination. Physiology and biochemistry. Gamma-aminobutyric acid. Tannin.

\section{INTRODUCTION}

Sorghum (Sorghum bicolor L. Moenc) is a major crop around the world with many unique characteristics. It has become an important source of energy, protein, minerals, antioxidant, vitamins and gluten free diet for the poor people of Africa and Asia (BELTON; TAYLOR 2004; DICKO et al., 2006). Therefore, the improvement of the available nutrients is critically important for food science (BELTON; TAYLOR 2004).

Many biochemical researches were conducted to enhancing the nutritional composition of sorghum. As a biochemical method, germination has been widely used to improve functional properties (GUAJARDO-FLORES et al., 2014, JANNOEY et al., 2010). Germination could modify sorghum protein composition and thus promoting its nutritional quality, as well as improve sorghum amino acid composition (CHAVAN et al., 1989). During germination, a large number of significant changes occur including activation of intrinsic amylases, proteases, and fiber-degrading enzymes (BENITEZ et al., 2013; LOYMA et al., 2012), etc., which partially degrade the complex substance into simple. Especially, gamma-aminobutyric acid (GABA) was accumulated significantly (YANG et al., 2013), while tannin and antinutritional factors were degraded or released (KHANDELWAL et al., 2010; LUO; XIE 2013).

In this study, the main physiology and biochemistry metabolism changes of sorghum seeds during germination was investigated. The objective of this study was to supply some data for developing sorghum food with high nutritional value and low content of anti-nutritional factors.

\section{MATERIAL AND METHODS}

\section{Materials}

Seeds of Sudanese sorghum cultivars locally known as Butanna, harvested in October 2012, were obtained from the Sudanese Arab company (Khartoum, Sudan). Acetonitrile was of highperformance liquid chromatography (HPLC) grade. Other chemicals and reagents were of analytical grade and purchased from Shanghai Institute of Biochemistry (Shanghai, China).

\section{Seed germination}

The sorghum seeds were surface-sterilized with $1.0 \%(\mathrm{v} / \mathrm{v})$ sodium hypochlorite for $30 \mathrm{~min}$ at room temperature $\left(25 \pm 2{ }^{\circ} \mathrm{C}\right)$ and then steeped in deionized water for $6 \mathrm{~h}$. Sorghum seeds were placed in a culture plat with filter paper and $10 \mathrm{~mL}$ of deionized water was added. Germination in the dark for three days at $32 \pm 2{ }^{\circ} \mathrm{C}$ and samples were taken every day. After germination, sprouts were collected and stored at $-20{ }^{\circ} \mathrm{C}$ until further analyses.

\section{Determination of biochemical composition}

Crude fat (solvent extraction), starch and crude protein (Kjeldahl, multiplying factor of 6.25) contents were determined according to standard 
Effect of germination...

methods (AOAC, 2000). Free amino acid content was estimated using aninhydrin colorimetric method. Reducing sugars were estimated using MILLER et al. (1959) method.

\section{Determination of germination percentage}

Germination percentage was determined during the three days of germination. The definition of seed germination was when the emerging radical elongated to $1 \mathrm{~mm}$. Germination percentage was calculated as follow:

$$
\mathrm{GR} \%=\frac{\text { No. of germinated seeds }}{\text { No. of total seeds }} \times 100 \text {. }
$$

\section{Determination of root length}

Twenty germinated sorghum seeds were taken as one sample group and calibrated by ruler $(\mathrm{cm})$ for measuring of the root length every $24 \mathrm{~h}$.

\section{Determination of respiratory rate}

Fresh germinated and ungerminated sorghum were put into sealed container at $28{ }^{\circ} \mathrm{C}$ for $1 \mathrm{~h}$. Then $\mathrm{CO}_{2}$ concentration was measured using an infrared gas analyzer (LB-BZ, Qingdao Loobo Environmental Protection Technology Co., Ltd, Qingdao, China). The respiratory rate was expressed as milligram per gram per hour.

\section{Determination of amino acid composition}

Amino acid composition was determined using amino acid analyzer (Hitachi L8900, Hitachi Co., Japan) according to the method described in AOAC (2000). Amino acids were expressed as g 100 $\mathrm{g}^{-1}$ protein on dry weight basis.

\section{Determination of GABA}

YANG, R. et al.

GABA content was determined according to Yang et al. (2013) using HPLC system (Agilent, GMI, Ramsey, MN, USA).

\section{Determination of Tannin}

Tannin content of germinated sorghum flour was determined according to the modified Vanillin$\mathrm{HCl}$ methanol method as described by Khandelwal et al. (2010)

\section{Statistical analysis}

An analysis of variance (ANOVA) of the data was performed, and a least significant difference (LSD) test with confidence interval of $95 \%$ was used to compare the means.

\section{RESULTS AND DISCUSSION}

Germination percentage, root length and respiratory rate of germinated sorghum

The change in germination percentages, root length and respiratory rate of sorghum seeds during germination are presented in Figure 1. About 97.1\% of the germination percentage was observed at the $1^{\text {st }}$ day of germination. Root length increased with germination, the length of the root reached $1.36 \mathrm{~cm}$ and $2.06 \mathrm{~cm}$ at the $2^{\text {nd }}$ and $3^{\text {rd }}$ day of germination, respectively. The consumption of oxygen in germinated sorghum seeds reaches its maximum rate between the $2^{\text {nd }}$ and $3^{\text {rd }}$ day of germination, a low rate of respiration metabolism was measured at the $1^{\text {st }}$ day. The respiration rate is related to the activation of vigorous enzymes in seeds. During germination, seeds consumed biochemical nutrients and energy, derived from the metabolism mechanism and the anabolic reactions.

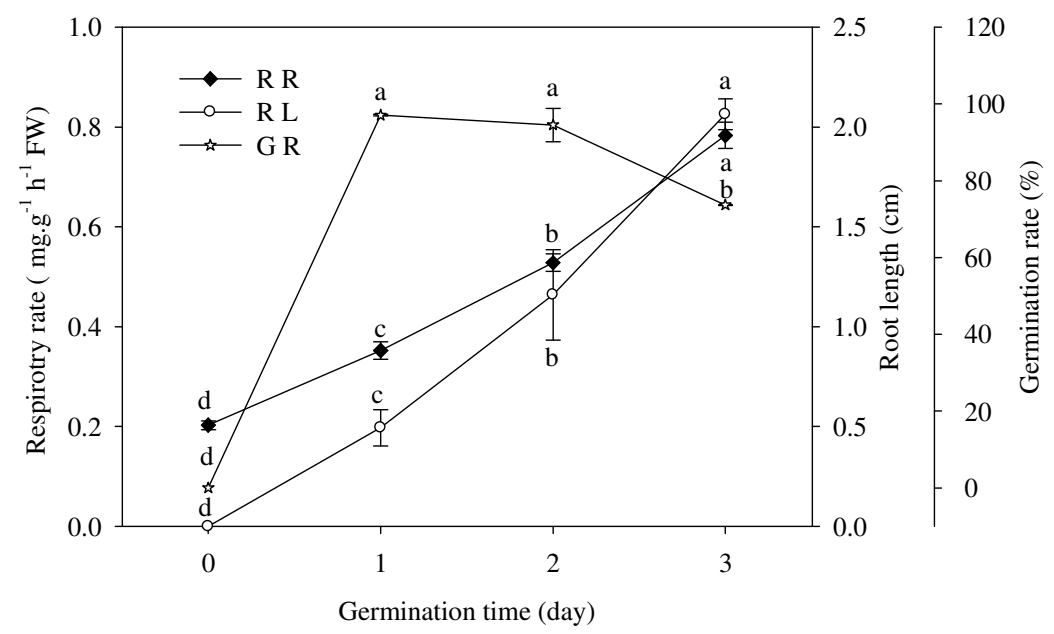

Figure 1. Changing pattern in germination rate (GR), root length (RL) and respiratory rate (RR) of sorghum during germination. Values are the means of triplicate analyses. Error bars show the standard deviation. Lower case letters reflect the significance of differences $(p<0.05)$. 
Effect of germination...

\section{Germination increased the small molecular nutrients of sorghum seeds}

The nutritional contents of germinated sorghum are shown in Table 1. Germination for 1,2 and 3 days showed significant difference $(p<0.05)$ in nutritional contents compared with the raw sorghum seeds. The contents of crude protein, crude fat and starch reduced, whereas that of free amino acids and reducing sugars increased with germination time. Free amino acids and reducing sugars increased by 2 and 4 folds at $3^{\text {rd }}$ day of germination, respectively. Germination caused degradation of the stored
YANG, R. et al.

nutrients like starch and protein to soluble sugars and free amino acids by hydrolytic enzymes to meet the seed requirements and the embryo growth. Crude fat, crude protein and starch are major sources of nutrients during germination. Starch and protein degradations indicated the interference with metabolic systems work on reserve starch and protein by the enzymes amylases and proteases. Fat content decreased during germination, because germinated seeds need another source of energy rather than sugars which have been already utilized.

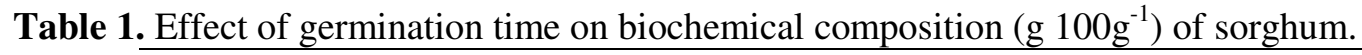

\begin{tabular}{lllll}
\hline \multirow{2}{*}{ Index } & \multicolumn{4}{c}{ Germination time (day) } \\
\cline { 2 - 5 } & \multicolumn{1}{c}{0} & \multicolumn{1}{c}{1} & \multicolumn{1}{c}{2} & \multicolumn{1}{c}{3} \\
\hline Starch & $69.42 \pm 1.69 \mathrm{a}$ & $66.21 \pm 0.62 \mathrm{~b}$ & $63.57 \pm 1.24 \mathrm{~b}$ & $60.08 \pm 2.14 \mathrm{c}$ \\
Protein & $9.99 \pm 0.34 \mathrm{a}$ & $9.15 \pm 0.28 \mathrm{~b}$ & $8.89 \pm 0.14 \mathrm{bc}$ & $8.65 \pm 0.12 \mathrm{c}$ \\
Crude fat & $4.74 \pm 6.8 \mathrm{a}$ & $3.52 \pm 0.10 \mathrm{~b}$ & $3.02 \pm 0.13 \mathrm{bc}$ & $3.22 \pm 0.06 \mathrm{bc}$ \\
Free amino acid & $0.82 \pm 0.01 \mathrm{c}$ & $0.95 \pm 0.06 \mathrm{c}$ & $1.27 \pm 0.8 \mathrm{~b}$ & $1.66 \pm 0.07 \mathrm{a}$ \\
Reducing sugar & $3.78 \pm 0.10 \mathrm{c}$ & $10.37 \pm 0.33 \mathrm{~b}$ & $10.45 \pm 0.05 \mathrm{~b}$ & $14.65 \pm 0.47 \mathrm{a}$ \\
\hline
\end{tabular}

Values are means and standard deviation of three determinations $(n=3)$. Values followed by different superscript letters in a column are significantly $(p<0.05)$ different from each other.

\section{Germination redistributed essential amino acid composition}

The nutritional value of food dietary protein can be assessed by measuring the type and quantity of essential amino acids present. The results showed that essential amino acids content in 1-day germinated sorghum was lower than that in raw (Table 2). But they were increasing with the germinating time. When germinating for 3 days, phenylalanine, lysine, methionine and tyrosine content increased by $14.49 \%$, $21.46 \%, 56.14 \%$ and $17.00 \%$, respectively, compared with that in raw. It could be concluded that germination enhanced the content of most of the essential amino acids especially limiting amino acids.

Table 2. Essential protein amino acids content $\left(\mathrm{g} 100 \mathrm{~g}^{-1}\right.$ protein) of sorghum cultivar Butana during germination.

\begin{tabular}{lcccc}
\hline \multirow{2}{*}{ Amino acid } & \multirow{2}{*}{ Raw } & \multicolumn{3}{c}{ Germinated time (day) } \\
\cline { 3 - 5 } & & 1 & 2 & 3 \\
\hline Leucine & $14.83 \pm 1.77 \mathrm{a}$ & $8.42 \pm 0.46 \mathrm{c}$ & $13.44 \pm 1.14 \mathrm{a}$ & $12.81 \pm 0.74 \mathrm{ab}$ \\
Threonine & $3.71 \pm 0.45 \mathrm{a}$ & $2.08 \pm 0.07 \mathrm{~b}$ & $3.54 \pm 0.12 \mathrm{a}$ & $3.87 \pm 0.21 \mathrm{a}$ \\
Valine & $6.30 \pm 0.33 \mathrm{a}$ & $4.13 \pm 0.56 \mathrm{~b}$ & $6.41 \pm 0.65 \mathrm{a}$ & $6.25 \pm 0.77 \mathrm{a}$ \\
Phenylalanine & $6.97 \pm 0.94 \mathrm{a}$ & $4.78 \pm 0.35 \mathrm{~b}$ & $7.38 \pm 0.33 \mathrm{a}$ & $7.98 \pm 0.12 \mathrm{a}$ \\
Lysine & $2.47 \pm 0.11 \mathrm{~b}$ & $1.47 \pm 0.04 \mathrm{c}$ & $2.65 \pm 0.06 \mathrm{~b}$ & $3.00 \pm 0.04 \mathrm{a}$ \\
Methionine & $1.14 \pm 0.08 \mathrm{~b}$ & $1.10 \pm 0.05 \mathrm{~b}$ & $1.03 \pm 0.09 \mathrm{~b}$ & $1.78 \pm 0.09 \mathrm{a}$ \\
Tyrosine & $4.00 \pm 0.24 \mathrm{~b}$ & $2.35 \pm 0.07 \mathrm{c}$ & $4.30 \pm 0.31 \mathrm{ab}$ & $4.68 \pm 0.05 \mathrm{a}$ \\
Isoleucine & $4.03 \pm 0.09 \mathrm{a}$ & $2.30 \pm 0.11 \mathrm{~b}$ & $3.95 \pm 0.17 \mathrm{a}$ & $4.23 \pm 0.34 \mathrm{a}$ \\
\hline
\end{tabular}

Values are means and standard deviation of three determinations $(n=3)$. Values followed by different superscript letters in a row are significantly $(p<0.05)$ different from each other.

\section{Germination increased GABA content of sorghum seeds}

There was a gradual and significant $(p<0.05)$ increase in GABA content during three days germination (Figure 2). Its content in germinated sorghum increased by about 5 times at the $3^{\text {rd }}$ day of germination. This enrichment may be due to the decrease in glutamate content (BAI et al., 2008), indicating that germination not only can increase essential protein amino acids, but also increase other non protein amino acids with functions such as GABA, etc. 


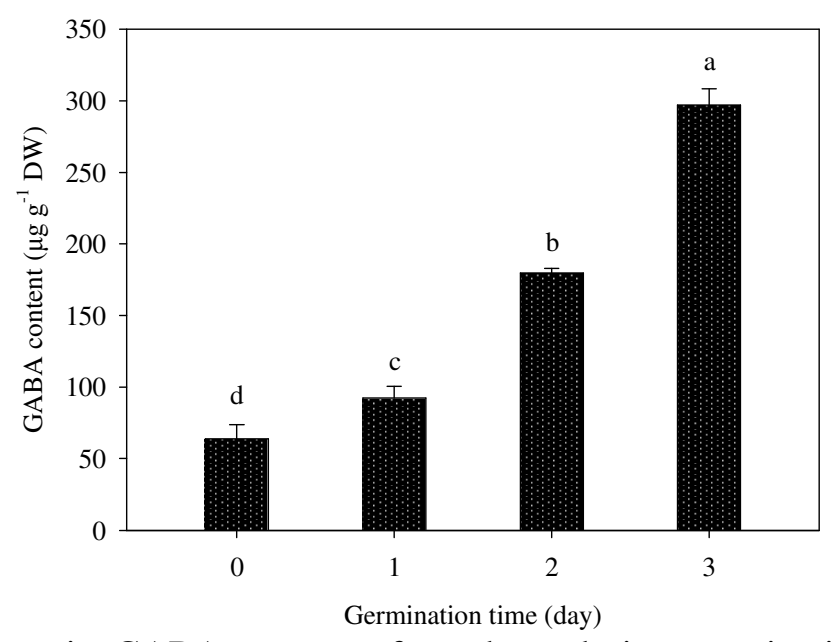

Figure 2. Changing patterns in GABA content of sorghum during germination. Values are the means of triplicate analyses. Error bars show the standard deviation. Lower case letters reflect the significance of differences $(p<0.05)$.

Germination converted binding tannin of sorghum seeds to free

Germination for 3 days recorded the highest tannin content (Figure 3). Generally, tannin is combined with protein, polysaccharide and cellulose, etc. in seeds. During germination, endogenous enzymes were activated to degrade storage substances to small micromolecular and tannin was released to be detectable significantly using conventional method (AHMED et al., 1996; ELKHIER; HAMID 2008). In addition, the kernel coat did not affect during the germination process, since tannins is condense there and the most edible part is the cotyledon. So that kernel coat is mare in weight compared with the remained cotyledon weight. Therefore, overall tannin content was increased. However, some researches reported that germination reduce the tannin content, this can be due to solubilisation by enzymes because germination promote the hydrolytic enzymes (DEWAR et al., 1997; IDRIS et al., 2006). In the present study, the results disagree with previous researches. Also this could be a result of solubilization of tannin when the seeds were soaked in water and migration of tannin to the outer layer during germination, as indicated by the browning of the germinated seeds.

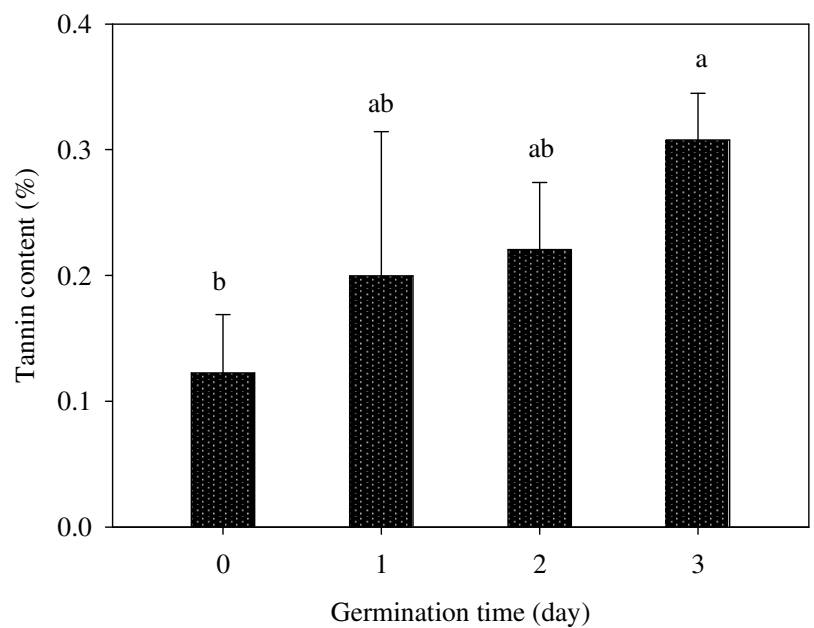

Figure 3. Tannin content during germination. Values are the means of triplicate analyses. Error bars show the standard deviation. Lower case letters reflect the significance of differences $(p<0.05)$.

\section{CONCLUSIONS}

The root length, respiratory rate, free amino acid and reducing sugar increased during sorghum germination, whereas a decreasing trend occurred in its germination rate, moisture content, crude protein, crude fat and starch content. 
Germination increased essential amino acids content especially for limiting amino acids. In addition, it was confirmed that germination increased GABA content while released tannin in sorghum. All these results supported that germination could improving nutrients of sorghum which can be used to produce functional food formulations particularly for children and geriatric people.

RESUMO: O principal metabolismo fisiologico e bioquímico incluindo composição de aminoácidos e teor em ácido gama-aminobutírico (GABA), do sorgo durante o período de germinação 3-dia foram investigados. A frequência respiratória aumentou durante a germinação. A atividade de proteases, aminoácidos livres e redução do teor de açúcar aumentou com o tempo de germinação. Enquanto umidade, proteína, gordura e teor de amido diminuiram, significativamente. Enquanto isso, a composição de aminoácidos redistribuído e o teor relativo de ácidos aminados essenciais aumentaram, exceto para leucina e valina. Além disso, alguns conteúdos não essenciais de aminoácidos, tais como prolina, glicina e histidina foram bem melhorados pela germinação. O conteúdo GABA aumentou cerca de 3 dobras após a germinação. Além disso, a combinação de tanino (o principal factor anti-nutricional) foi convertido para ser livre e solúvel. Estes resultados sugerem fortemente que o sorgo germinado pode ser um alimento funcional rico em GABA e outros nutrientes que promovem a saúde.

PALAVRAS-CHAVE: Sorghum. Germinação. Fisiologia e bioquímica. Ácido gama-aminobutírico. Tanino.

\section{REFERENCES}

AHMED, S.; MAHGOUB, S.; BABIKER, B. Changes in tannin and cyanide contents and diastic activity during germination and the effect of traditional processing on cyanide content of sorghum cultivars. Food Chemistry, London, v. 56, p. 159-162, 1996.

AOAC. 2000. Official methods of analysis of the association of official analytical chemists.

BAI, Q.; FAN, G.; GU, Z.; CAO, X.; GU, F. Effects of culture conditions on $\gamma$-aminobutyric acid accumulation during germination of foxtail millet (Setaria italica L.). European Food Research and Technology, Berlin, v. 228, p. 169-175, 2008 .

BELTON, P. S.; TAYLOR, J. Sorghum and millets: protein sources for Africa. Trends in Food Science and Technology, Cambridge, v. 15, p. 94-98, 2004.

BENITEZ, V.; CANTERA, S.; AGUILERA, Y.; MOLLA, E.; ESTEBAN, R. M.; FELICIA DIAZ, M.; MARTINCABREJAS, M. A. Impact of germination on starch, dietary fiber and physicochemical properties in non-conventional legumes. Food Research International, Barking, v. 50, p. 64-69, 2013.

CHAVAN, J.; KADAM, S.; BEUCHAT, L. R. Nutritional improvement of cereals by fermentation. Critical Reviews in Food Science and Nutrition, Boca Raton, v. 28, p. 349-400, 1989.

DEWAR, J.; TAYLOR, J.; BERJAK, P. Determination of improved steeping conditions for sorghum malting. Journal of Cereal Science, v. 26, p. 129-136, 1997.

DICKO, M. H.; GRUPPEN, H.; TRAOR , A. S.; VORAGEN, A. G. J.; VAN BERKEL, W. J. H. Review: sorghum grain as human food in Africa: relevance of starch content and amylase activities. African Journal of Biotechnology, v. 5, p. 384-395, 2006.

ELKHIER, M. K. S.; HAMID, A. O. Effect of malting on the chemical constituents, anti-nutrition factors, and ash composition of two sorghum cultivars (Feterita and Tabat) grown in Sudan. Research Journal of Agricultre and Biologycal Science, v. 4, p. 500-504, 2008. 
GUAJARDO-FLORES, D.; SERNA-GUERRERO, D.; SERNA-SALDIVAR, S. O.; JACOBO-VELAZQUEZ, D. A. Effect of germination and UV-C radiation on the accumulation of flavonoids and saponins in black bean seed coats. Cereal Chemistry, Saint Paul, v. 91, p. 276-279, 2014.

IDRIS, W. H.; ABDELRAHAMAN, S. M.; ELMAKI, H. B.; BABIKER, E. E.; EL TINAY, A. H. Effect of malt pretreatment on phytate and tannin level of two sorghum (Sorghum bicolor) cultivars. International Journal of Food Science and Technology, Oxford, v. 41, p. 1229-1233, 2006.

JANNOEY, P.; NIAMSUP, H.; LUMYONG, S.; TAJIMA, S.; NOMURA, M.; CHAIROTE, G. Gamma-aminobutyric acid (GABA) accumulations in rice during germination. Chiang Mai Journal of Science, v. 37, p. 124-133, 2010.

KHANDELWAL, S.; UDIPI, S. A.; GHUGRE, P. Polyphenols and tannins in Indian pulses: Effect of soaking, germination and pressure cooking. Food Research International, Barking, v. 43, p. 526-530, 2010.

LOYMA, D.; PHOTCHANACHAI, S.; RITTHICHAI, P. Changes in amylase activity, reducing sugar, and free fatty acid in wax gourd benincasa hispida (Thunb.) cogn. seeds during germination and the effects of scarification. Asia Pacific Symposium on Postharvest Research, Education and Extension, v. 943, p. 137-142, 2012.

LUO, Y.-W.; XIE, W.-H. Effect of germination conditions on phytic acid and polyphenols of faba bean sprouts (Vicia Faba L.). Legume Research, v. 36, p. 489-495, 2013.

MILLER, G. L. Use of dinitrosalicylic acid reagent for determination of reducing sugar. Analytical Chemistry, Washington, v. 31, p. 426-428, 1959.

YANG, R.; GUO, Q.; GU, Z. GABA shunt and polyamine degradation pathway on $\gamma$-aminobutyric acid accumulation in germinating fava bean (Vicia faba L.) under hypoxia. Food Chemistry, London, v. 136 p. 152-159, 2013. 